\title{
Fossil and non-fossil sources of organic carbon (OC) and elemental carbon (EC) in Göteborg, Sweden
}

\author{
S. Szidat ${ }^{1,2}$, M. Ruff ${ }^{1,2}$, N. Perron ${ }^{2}$, L. Wacker $^{3}$, H.-A. Synal ${ }^{3}$, M. Hallquist ${ }^{4}$, A. S. Shannigrahi ${ }^{4}$, K. E. Yttri ${ }^{5}$, C. Dye ${ }^{5}$, \\ and D. Simpson ${ }^{6,7}$ \\ ${ }^{1}$ Department of Chemistry and Biochemistry, University of Berne, Freiestrasse 3, 3012 Berne, Switzerland \\ ${ }^{2}$ Paul Scherrer Institut, 5232 Villigen-PSI, Switzerland \\ ${ }^{3}$ Institute for Particle Physics, ETH Hönggerberg, 8093 Zurich, Switzerland \\ ${ }^{4}$ Department of Chemistry, Atmospheric Science, University of Gothenburg, 41296 Gothenburg, Sweden \\ ${ }^{5}$ Norwegian Institute for Air Research, 2027 Kjeller, Norway \\ ${ }^{6}$ Norwegian Meteorological Institute, 0313 Oslo, Norway \\ ${ }^{7}$ Radio and Space Science, Chalmers University of Technology, 41296 Gothenburg
}

Received: 10 July 2008 - Published in Atmos. Chem. Phys. Discuss.: 26 August 2008

Revised: 3 December 2008 - Accepted: 10 February 2009 - Published: 2 March 2009

\begin{abstract}
Particulate matter was collected at an urban site in Göteborg (Sweden) in February/March 2005 and in June/July 2006. Additional samples were collected at a rural site for the winter period. Total carbon (TC) concentrations were $2.1-3.6 \mu \mathrm{g} \mathrm{m}^{-3}, 1.8-1.9 \mu \mathrm{g} \mathrm{m}^{-3}$, and 2.2$3.0 \mu \mathrm{g} \mathrm{m}^{-3}$ for urban/winter, rural/winter, and urban/summer conditions, respectively. Elemental carbon (EC), organic carbon (OC), water-insoluble OC (WINSOC), and watersoluble $\mathrm{OC}$ (WSOC) were analyzed for ${ }^{14} \mathrm{C}$ in order to distinguish fossil from non-fossil emissions. As wood burning is the single major source of non-fossil EC, its contribution can be quantified directly. For non-fossil OC, the wood-burning fraction was determined independently by levoglucosan and ${ }^{14} \mathrm{C}$ analysis and combined using Latin-hypercube sampling (LHS). For the winter period, the relative contribution of EC from wood burning to the total EC was $>3$ times higher at the rural site compared to the urban site, whereas the absolute concentrations of EC from wood burning were elevated only moderately at the rural compared to the urban site. Thus, the urban site is substantially more influenced by fossil EC emissions. For summer, biogenic emissions dominated OC concentrations most likely due to secondary organic aerosol (SOA) formation. During both seasons, a more pronounced fossil signal was observed for Göteborg than has previously been reported for Zurich, Switzerland. Analysis of air mass
\end{abstract}

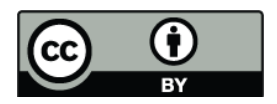

Correspondence to: S. Szidat

(szidat@iac.unibe.ch) origin using back trajectories suggests that the fossil impact was larger when local sources dominated, whereas longrange transport caused an enhanced non-fossil signal. In comparison to other European locations, concentrations of levoglucosan and other monosaccharide anhydrides were low for the urban and the rural site in the area of Göteborg during winter.

\section{Introduction}

Airborne particulate matter (PM) influences the radiation budget directly by scattering of sunlight and indirectly by cloud formation. Furthermore, it causes respiratory as well as cardiovascular diseases (Knaapen et al., 2004). As a ubiquitous component of PM, carbonaceous aerosols substantially contribute to these climate and health effects (Jacobson et al., 2000; Kanakidou et al., 2005). Elemental carbon (EC), which is optically absorptive and highly polyaromatic, has enhanced negative repercussions on human health (Knaapen et al., 2004). Organic carbon (OC) is the non-absorptive fraction of the carbonaceous aerosol, which has a lower molecular weight than EC. It may contain reactive compounds, which take part in atmospheric-chemical transformations and enhance condensation of clouds (Tsigaridis et al., 2006) or act as toxins and allergens.

Published by Copernicus Publications on behalf of the European Geosciences Union. 
In spite of the importance of the carbonaceous aerosol, detailed apportionment and quantification of its sources is still difficult due to the large number of sources and the vast number of organic compounds associated with the aerosol (Kanakidou et al., 2005). In general, EC enters the atmosphere exclusively as a primary (i.e. direct particulate) emission originating nearly completely from pyrolysis during incomplete combustion, e.g. due to traffic, industrial incineration, or biomass burning (Bond et al., 2007). The OC fraction includes primary particles and secondary organic aerosols (SOA), whereof the latter is formed from gaseous precursors by atmospheric oxidation or oligomerization (Jacobson et al., 2000; Kanakidou et al., 2005; Tsigaridis et al., 2006). OC originates from anthropogenic sources, e.g. from combustion processes in line with EC emissions. Besides these sources, primary biogenic emissions and SOA formation play an important role for the OC fraction, especially during summer. However, the actual production pathways and emission strengths of both, primary biogenic particles and SOA, are still poorly understood (Kanakidou et al., 2005). Additionally, numerous minor OC sources exist, which largely differ seasonally and locally. Prevalent waterinsoluble OC (WINSOC) components are alkanes, alkanals, alkanons, waxes, proteins, plant fragments, and small living organisms (bioaerosols); water-soluble OC (WSOC) typically consists of oxygenated compounds (often from secondary production) as di- and polycarboxylic acids, fatty acids, as well as carbohydrates and their derivatives (Pöschl, 2005).

The above-mentioned sources all have complex emission and transformation regimes, which make inventory-based emission estimation challenging. Therefore, receptor models aim to re-construct the origin and emissions based on ambient concentrations of source-specific markers (e.g., organic compounds, inorganic tracers, or mass fragments of direct PM analyzing mass spectrometers) using model-derived or a priori established emission factors (Schauer et al., 1996; Hopke et al., 2006; Alfarra et al., 2007). This approach assumes that these emission factors are independent of changing emission conditions or chemical transformations during atmospheric alteration. Whereas such assumptions are typically valid only under certain circumstances (e.g., close to emissions or for similar sites), they are much less problematic for many isotopic tracers. For carbonaceous particles, radiocarbon $\left({ }^{14} \mathrm{C}\right)$ is such an isotopic tracer, by which fossil and non-fossil emissions can be distinguished (Currie, 2000; Lewis et al., 2004; Szidat, 2009). With this technique, the contribution of biogenic and fossil OC for summer conditions (Szidat et al., 2004a, b) as well as the fraction of EC from residential wood burning during winter was directly quantified for several Swiss sites (Szidat et al., 2006, 2007). Furthermore, the combination of ${ }^{14} \mathrm{C}$ analysis with other apportionment tools such as aerosol mass spectrometry (Alfarra et al., 2007), multi-wavelength aerosol light absorption measurements (Sandradewi et al., 2008a), organic tracer determination (Gelencsér et al., 2007), and aerosol modeling (Simpson et al., 2007) has recently gained new insights into sources of carbonaceous aerosols.

Levoglucosan is the most recognized molecular marker for tracing emissions of particulate matter from biomass burning. It is emitted in high concentrations, not present in the vapour phase, and predominantly associated with fine aerosols (Locker, 1988; Simoneit et al., 1999; Yttri et al., 2005). According to present knowledge it is not selectively removed from the atmosphere (Fraser and Lakshamaran, 2000). The stability of the levoglucosan/OC emission ratio for different burning conditions is somewhat controversial. Jordan and Seen (2005) stated that this ratio is stable for a wide range of burn rates, whereas many compilations of literature results (e.g., Szidat et al., 2006; Puxbaum et al., 2007; Sandradewi et al., 2008b) show quite variable relationships. However, levoglucosan enables detection of plumes from biomass burning and make it possible to study temporal variations of wood burning emissions on a sub-daily scale.

The present work employs ${ }^{14} \mathrm{C}$ and levoglucosan determinations for two locations (urban and rural) in South-West Sweden in order to investigate the different source patterns of carbonaceous aerosols for this part of Scandinavia. Northern Europe provides a number of interesting conditions for investigating sources of carbonaceous aerosols. (1) Large forested areas are likely to give a greater proportion of biogenic to anthropogenic VOCs and aerosols than for other parts of Europe. (2) Wood-burning is quite common: one third of Swedish homes are completely or partially heated by burning of firewood (Hedberg et al., 2002). Glasius et al. (2006) stated that the number of wood-combustion appliances in Denmark has doubled during the last decade and demonstrated that wood combustion can result in local particle levels comparable to heavily trafficked streets. (3) Modeled SOA contributions to OC close to $100 \%$ are reported for Scandinavia both for summer and winter, which is on the regional scale substantially higher than for Central Europe (Simpson et al., 2007): in summer, the combination of high forest density and increased day length promote photochemical reactions of biogenic VOCs; in winter, low temperatures favor condensation of semi-volatile organic gases (Andersson-Sköld and Simpson, 2001; Simpson et al., 2007).

In this work, we present an assessment through ${ }^{14} \mathrm{C}$ analysis of the contribution of fossil versus non-fossil carbon to ambient aerosols in and close to Göteborg in SouthWest Sweden. Combined with the measurements of levoglucosan, this complementary ${ }^{14} \mathrm{C}$ analysis provides a good estimate of the relative roles of biogenic VOC, anthropogenic wood-burning, and fossil combustion sources to EC and OC. Furthermore, the comparison of summer and winter results yields insight into the seasonal cycle of anthropogenic vs. biogenic contributions to the atmospheric aerosol. 
Table 1. Conditions of aerosol sampling.

\begin{tabular}{|c|c|c|c|}
\hline Campaign & Winter, urban & Winter, rural & Summer, urban \\
\hline $\begin{array}{l}\text { Sampling } \\
\text { period }\end{array}$ & $\begin{array}{l}11 \text { February - } \\
4 \text { March } 2005\end{array}$ & $\begin{array}{l}14 \text { February - } \\
25 \text { February } 2005\end{array}$ & $\begin{array}{l}13 \text { June }- \\
4 \text { July } 2006\end{array}$ \\
\hline Site & Femman & Råö & Femman \\
\hline Position & $\begin{array}{l}57^{\circ} 42^{\prime} \mathrm{N}, 11^{\circ} 57^{\prime} \mathrm{E} \\
20 \mathrm{~m} \text { a.s.l. }\end{array}$ & $\begin{array}{l}57^{\circ} 24^{\prime} \mathrm{N}, 11^{\circ} 55^{\prime} \mathrm{E}, \\
10 \mathrm{~m} \text { a.s.l. }\end{array}$ & $\begin{array}{l}\text { See winter, } \\
\text { urban }\end{array}$ \\
\hline Location & $\begin{array}{l}\text { Downtown Göteborg, } \\
\text { ( } 600000 \text { inhabitants) } \\
\text { rooftop position }\end{array}$ & $\begin{array}{l}2 \text { km SW of Råö, } \\
\text { ground position }\end{array}$ & $\begin{array}{l}\text { See winter, } \\
\text { urban }\end{array}$ \\
\hline Vicinity & $\begin{array}{l}\text { Shopping, residential, } \\
\text { and industrial areas }\end{array}$ & $\begin{array}{l}\text { Forest, heath, } \\
\text { sea shore }\end{array}$ & $\begin{array}{l}\text { See winter, } \\
\text { urban }\end{array}$ \\
\hline $\begin{array}{l}\text { Sampling } \\
\text { system }\left({ }^{14} \mathrm{C}\right)\end{array}$ & $\begin{array}{l}\text { Sierra-Andersen GMW } \\
\text { HiVol Air Sampler }\end{array}$ & $\begin{array}{l}\text { Anderson } 65-800 \\
\text { Two-Stage HiVol } \\
\text { Cascade Impactor }\end{array}$ & $\begin{array}{l}\text { Anderson } 65-800 \\
\text { Two-Stage HiVol } \\
\text { Cascade Impactor }\end{array}$ \\
\hline $\begin{array}{l}\text { Sampling system } \\
\text { (levoglucosan) }\end{array}$ & $\begin{array}{l}\text { Flow: } 1130 \mathrm{~L} \mathrm{~min}^{-1} \\
\text { Inlet: } \mathrm{PM}_{10} \\
\text { Derenda LVS3 } \\
\text { Flow: } 38 \mathrm{~L} \mathrm{~min}^{-1} \\
\text { Inlet: } \mathrm{PM}_{2.5}\end{array}$ & $\begin{array}{l}\text { Flow: } 480 \mathrm{~L} \mathrm{~min}^{-1} \\
\text { Inlet: } \mathrm{PM}_{2.5} \\
\text { Identical to }{ }^{14} \mathrm{C}\end{array}$ & $\begin{array}{l}\text { Flow: } 480 \mathrm{~L} \mathrm{~min}^{-1} \\
\text { Inlet: } \mathrm{PM}_{2.5} \\
\text { Identical to }{ }^{14} \mathrm{C}\end{array}$ \\
\hline
\end{tabular}

\section{Methods}

\subsection{Particulate matter sampling}

In February/March 2005 and June/July 2006, aerosol filter samples were collected for subsequent analysis of its carbonaceous content during the Göte-2005 campaign (Hallquist et al., 2009) in the area of Göteborg, Sweden. Sampling during winter was conducted simultaneously at the urban site Femman and the rural EMEP site Råö (SE14), which is located $35 \mathrm{~km}$ south of Göteborg. During summer, sampling was conducted at the urban site only. The urban site is situated at an approximate height of $30 \mathrm{~m}$ above ground level in down-town Göteborg on top of the 7-floor-high department store Femman. This site is the main air quality monitoring site in Göteborg where routine measurements are conducted by the Environmental Office in Göteborg.

The aerosol was collected on pre-heated quartz fiber filters (Pallflex 2500QAT-UP) using different samplers, inlets, and air flows. For details see Table 1. During the winter campaign sampling was conducted using different inlets, i.e. $\mathrm{PM}_{10}$ at Femman and $\mathrm{PM}_{2.5}$ at Råö. These data are only fully comparable for conditions when the fine (particle diameters $<2.5 \mu \mathrm{m}$ ) fraction dominates the organic load. On the average, normalized $\mathrm{PM}_{2.5} / \mathrm{PM}_{10}$ ratios for Femman were 0.80 and 0.96 for TC and EC, respectively, which indicates that coarse organic fractions might have influenced this comparability. After sampling, filters were folded, wrapped in aluminum foil, packed into air-tight plastic bags, and stored at $-20^{\circ} \mathrm{C}$. During transportation, the filter samples experienced ambient temperatures for $48 \mathrm{~h}$. Blank filters were treated in the same way as the exposed filters without collection of aerosols.

\subsection{Separation of carbonaceous particle fractions}

The chemical separation of OC, WINSOC, and EC from the quartz fiber filters for ${ }^{14} \mathrm{C}$ measurement using a step-wise oxidation (Szidat et al., 2004c) was described elsewhere (Szidat et al., 2004a, 2006, 2007). In brief, OC is oxidized at $340^{\circ} \mathrm{C}$ in a stream of pure oxygen. For WINSOC analysis, watersoluble compounds are removed by water extraction of the filter. The remaining carbon on the filter is then treated as for OC separation. The level of WSOC is determined by subtraction of WINSOC from OC. EC is oxidized at $650^{\circ} \mathrm{C}$ after complete removal of $\mathrm{OC}$ and interfering water-soluble inorganic compounds, which is done by extraction with diluted hydrochloric acid and water followed by pre-heating in air at $390^{\circ} \mathrm{C}$ for $4 \mathrm{~h} . \mathrm{CO}_{2}$ evolving from OC, WINSOC, and EC is cryo-trapped and sealed in ampoules for ${ }^{14} \mathrm{C}$ measurement.

For correct ${ }^{14} \mathrm{C}$ analysis of EC, suppression of the positive artifact during OC removal ("charring") is of special importance. Charring will produce additional EC so the ${ }^{14} \mathrm{C}$ measurement of EC may then be biased, as charred OC and EC often have largely different isotopic signals (Szidat et al., 2004a). The suppression of charring is optimized especially by the water extraction and the oxidative treatment of the filters. This was revealed by on-line monitoring of the optical properties of the filters during the thermal treatment, which showed that charring contributed only by $\leq 4 \%$ to EC for filters analyzed in this work. Details are given elsewhere (Perron et al., 2009; see also Szidat et al., 2008).

Wittmaack (2005) observed that bioaerosols may remain partially on the filter after pre-heating in air. This implies that the EC fraction in aerosol matter larger than $\mathrm{PM}_{1}$ may be overestimated due to these coarse WINSOC residues, causing elevated $f_{M}$ (EC) values. Due to the seasonal distribution 
Table 2. Central values with low and high limits of input parameters for source apportionment using LHS.

\begin{tabular}{lccc}
\hline Parameter & Low limit & Central value & High limit \\
\hline EC error factor* & 0.75 & 1.00 & 1.25 \\
$f_{M, \text { wood }}$ & 1.11 & 1.16 & 1.21 \\
$f_{M, \text { nonfossil }}$ & 1.08 & 1.11 & 1.14 \\
(OC/EC) $)_{\text {wood }}$ & 4.83 & 6.37 & 9.35 \\
$(\text { OC/lev })_{\text {wood }}$ & 5.5 & 10 & 14 \\
\hline
\end{tabular}

* EC values multiplied by given factor.

of bioaerosols (Wittmaack, 2005), this artifact should be more important for summer than for winter.

The concentrations of the carbonaceous fractions are determined using a modified procedure of that reported by $\mathrm{La}-$ vanchy et al. (1999). TC is quantified manometrically as $\mathrm{CO}_{2}$ from the oxidation of the untreated filter at $650^{\circ} \mathrm{C}$. For EC measurement, $\mathrm{OC}$ is eliminated by water extraction and preheating at $375^{\circ} \mathrm{C}$ during $40 \mathrm{~min}$.

\section{$2.3{ }^{14} \mathrm{C}$ measurements}

${ }^{14} \mathrm{C}$ from the evolved $\mathrm{CO}_{2}$ was analyzed in carbon amounts of $10-70 \mu \mathrm{g}$ with accelerator mass spectrometry (AMS) at the ETH AMS facility, using two different techniques. For the majority of the samples collected during the winter campaign, $\mathrm{CO}_{2}$ was reduced with a mixture of $\mathrm{Co}$ and $\mathrm{Mn}$, forming filamentous carbon (Szidat et al., 2004c). This material served as the target material in the $500 \mathrm{kV}$ pelletron AMS system, which is equipped with a MC SNICS cesium sputter ion source for solid targets (Synal et al., 2000). Due to isotopic fractionation effects and chemical contamination during the reduction step, correction of raw data is laborious and, sometimes, induces large uncertainties (Jenk et al., 2007). For three of the samples collected at Råö in winter (14-18 February, WINSOC and EC, and 18-25 February, WINSOC) and for all those collected in summer, $\mathrm{CO}_{2}$ was mixed with $\mathrm{He}$ and transferred into a self-constructed cesium sputter gas ion source of the $200 \mathrm{kV}$ mini-radiocarbon dating system MICADAS (Ruff et al., 2007). The latter method enables ${ }^{14} \mathrm{C}$ determinations with a higher reliability and less uncertainty compared to the former one and is only subjected to negligible chemical contamination. An intercomparison revealed that both methods produce consistent results. ${ }^{14} \mathrm{C}$ measurements are given in fractions of modern carbon $\left(f_{M}\right)$, which denote the ${ }^{14} \mathrm{C} /{ }^{12} \mathrm{C}$ ratios of the samples related to that of the reference year 1950. According to Stuiver and Polach (1977), these values are decay-corrected for the time period between 1950 and the date of measurement.

\subsection{Levoglucosan determination}

Quantification of monosaccharide anhydrides (MA) (levoglucosan, mannosan and galactosan) in the aerosol filter samples was performed according to the method described in detail by Dye and Yttri (2005). In brief, punches $\left(1.5-3 \mathrm{~cm}^{2}\right)$ of the quartz fiber filter were soaked in tetrahydrofuran $(2 \mathrm{ml})$ and subjected to ultrasonic agitation $(30 \mathrm{~min})$. The filter extract were filtered through a syringe filter $(0.45 \mu \mathrm{m})$ to remove PM and filter parts. Each filter was extracted twice. The extracted volumes were pooled and evaporated to a total volume of $1 \mathrm{ml}$ in a nitrogen atmosphere. Before analysis the sample solvent elution strength was adapted to the mobile phase by adding Milli-Q water $(0.8 \mathrm{ml})$. The concentrations of MAs were determined using High Performance Liquid Chromatography (HPLC; Agilent 1100) in combination with HRMS-TOF (high resolution mass spectrometry based on a time-of-flight principle; Micromass LCT) operated in the negative electrospray mode. Levoglucosan, mannosan, and galactosan were identified on the basis of retention time and mass spectra of authentic standards. The limit of quantification of the current method is $30 \mathrm{pg}$ at a signal-to-noise ratio of 10 .

\subsection{Source apportionment of EC and OC}

Source apportionment of fossil and wood-burning EC $\left(\mathrm{EC}_{\text {fossil }}, \mathrm{EC}_{\mathrm{wood}}\right)$, as well as fossil and non-fossil $\mathrm{OC}$ $\left(\mathrm{OC}_{\text {fossil }}, \mathrm{OC}_{\text {nonfossil }}\right)$ is based on determination of $\mathrm{EC}, \mathrm{OC}$ and TC concentrations and ${ }^{14} \mathrm{C}$ isotopic ratios $\left(f_{M}(\mathrm{OC})\right.$, $f_{\mathrm{M}}(\mathrm{EC})$ ) (Szidat et al., 2006). $\mathrm{EC}$ is distinguished into $\mathrm{EC}_{\text {fossil }}$ and $\mathrm{EC}_{\text {wood. }} \mathrm{OC}$ is separated into $\mathrm{OC}_{\text {fossil }}$ and $\mathrm{OC}_{\text {nonfossil }}$, of which the second fraction comprises $\mathrm{OC}_{\mathrm{bio}}$ and $\mathrm{OC}_{\mathrm{wood}}$. In order to differentiate between the latter two sources, $\mathrm{OC}_{\text {wood }}$ is estimated using two independent techniques, namely $\mathrm{EC}_{\mathrm{wood}}$ and levoglucosan measurements using average emission ratios for residential wood burning in fireplaces (i.e., (OC/EC) $)_{\text {wood }}$ as given by Szidat et al. (2006) and $(\mathrm{OC} / \mathrm{lev})_{\text {wood }}$ as discussed in Sect. 3.4). $\mathrm{OC}_{\mathrm{bio}}$ is determined by subtraction of $\mathrm{OC}_{\mathrm{wood}}$ from $\mathrm{OC}_{\text {nonfossil }}$.

In order to allow for the multitude of possible combinations of parameters, an effective statistical approach known as Latin-hypercube sampling (LHS) was used, which is comparable to Monte Carlo calculations. Details of this procedure are given by Gelencsér et al. (2007). In brief, central values with low and high limits are associated to all uncertain input parameters (Table 2). These factors are combined using a simplified approach of LHS applying the software available at http://people.scs.fsu.edu/ burkardt/f_src/ihs/ihs.html. Due to the paucity of information on the input factors, parameters are assigned equally between the low limit and the central value and between the central value and the high limit. All valid combinations of parameters (i.e. excluding those producing negative contributions) are condensed in frequency distributions of possible solutions. 
Ambient carbonaceous particles are assumed as a mixture originating from sources with pure isotopic signals. The following $f_{M}$ figures have been applied for pure fossil, biogenic, and wood-burning sources: $f_{M \text {, fossil }}=0, f_{M \text {, bio }}=1.055$, $f_{M, \text { wood }}=1.16 \pm 0.05$. The values of the contemporary carbon sources ( $f_{M \text {, bio }}$ and $\left.f_{M \text {,wood }}\right)$, which are elevated compared to the theoretical modern level of 1 due to the nuclearbomb excess, are updated compared to earlier studies (Szidat et al., 2004a, 2006, 2007): $f_{M}$, bio for 2005/2006 was taken from the long-term time series of ${ }^{14} \mathrm{CO}_{2}$ measurements at the rural site Schauinsland (Levin and Kromer, 2004; Levin

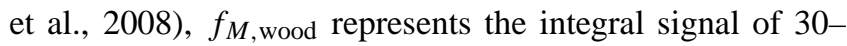
50 -year-old trees which were harvested in 2004 based on a tree growth model (Lewis et al., 2004; Mohn et al., 2008). For the source apportionment of the sub-fractions of OC, $f_{M}$ (WINSOC) was measured directly and $f_{M}$ (WSOC) was determined by concentration-weighed balancing of isotopic values of WINSOC and OC. These fractions were distinguished between fossil and non-fossil origin without further analysis of the latter portion into wood-burning and biogenic sources due to highly uncertain WINSOC/OC emission ratios.

\section{Results and discussion}

\subsection{Air mass origin}

10-days FLEXTRA back trajectories (Stohl and Seibert, 1998) with a time resolution of $6 \mathrm{~h}$ were analyzed for the rural site Råö during the campaign. Due to the proximity of both locations and the simple topography of the landscape, aerosol contributions from long-range transport are assumed equal for the two sites with additional contributions of local sources, urban and rural, respectively. The borderline of regional sources is more complex due to local wind patterns in the Göteborg area which may occur due to the proximity to the coast and moderate surrounding hills (Klingberg et al., 2009). However, during stable weather conditions, prevailing wind directions and air mass origin at the sampling sites were similar for several days, hence the main source regions can be deduced for the sampling periods as presented in Table 3. The accuracy of this source region analysis suffers somewhat from the uncertainties of the back trajectories (Stohl and Seibert, 1998). Furthermore, unstable weather conditions resulted in a mixture of air masses. Such episodes, which were more frequent during the summer campaign, were identified by divergence of trajectories arriving at different heights. Due to these limitations, the main source regions summarized in Table 3 have to be regarded with some caution. Typical 10-days back trajectories are shown in Figs. 1 and 2.

For the winter campaign, the air masses frequently arrived from western, northern, and eastern directions, transporting particulate matter from the Atlantic Ocean, Scandinavia
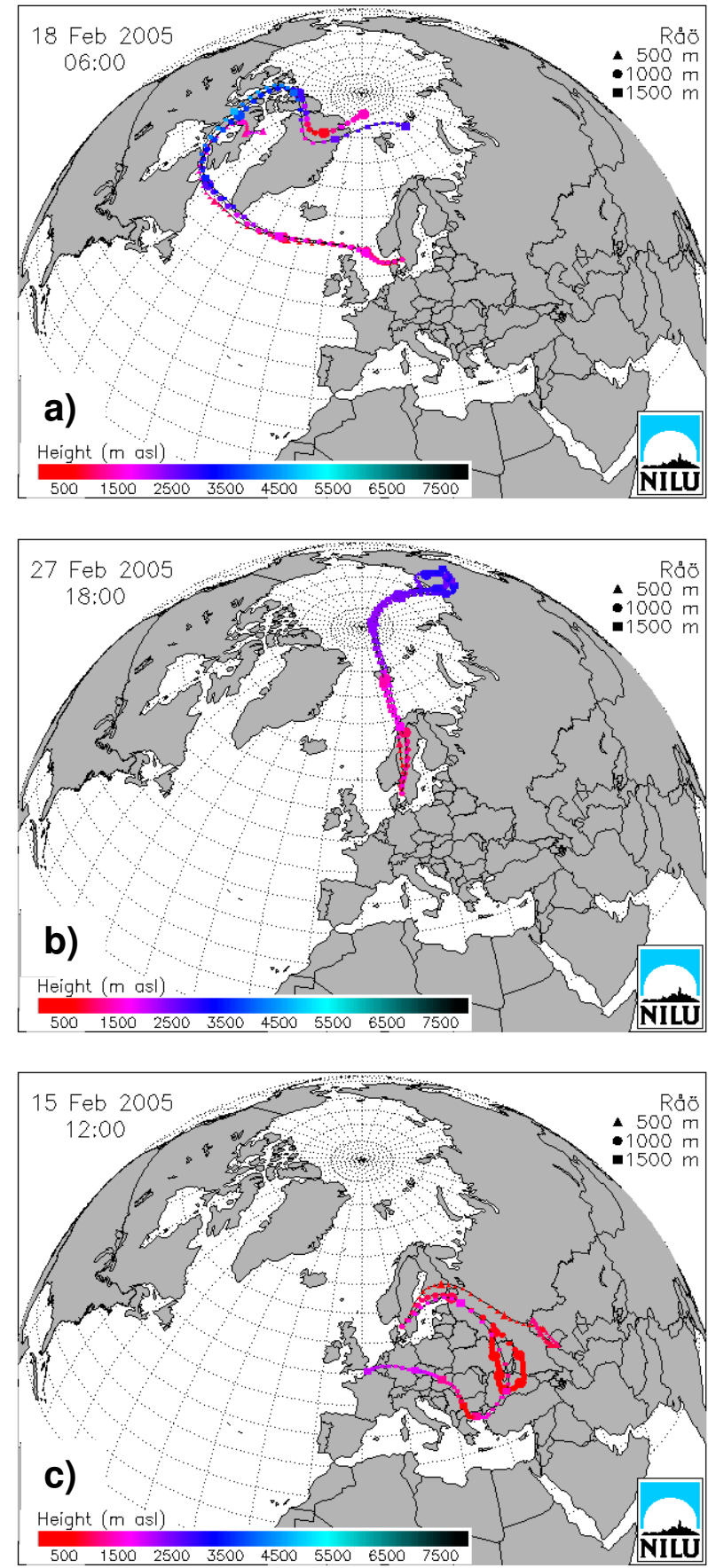

Fig. 1. Examples of FLEXTRA ten-days back trajectories (Stohl and Seibert, 1998) for air masses reaching Råö, which originate from the North Atlantic Ocean (a), North Scandinavia (b), and Eastern Europe (c) during winter 2005.

north of Göteborg, and Central/Eastern Europe, respectively. Air masses from the Atlantic Ocean are likely to consist of rather clean marine air, while air masses from the eastern sector are likely to contribute significantly 

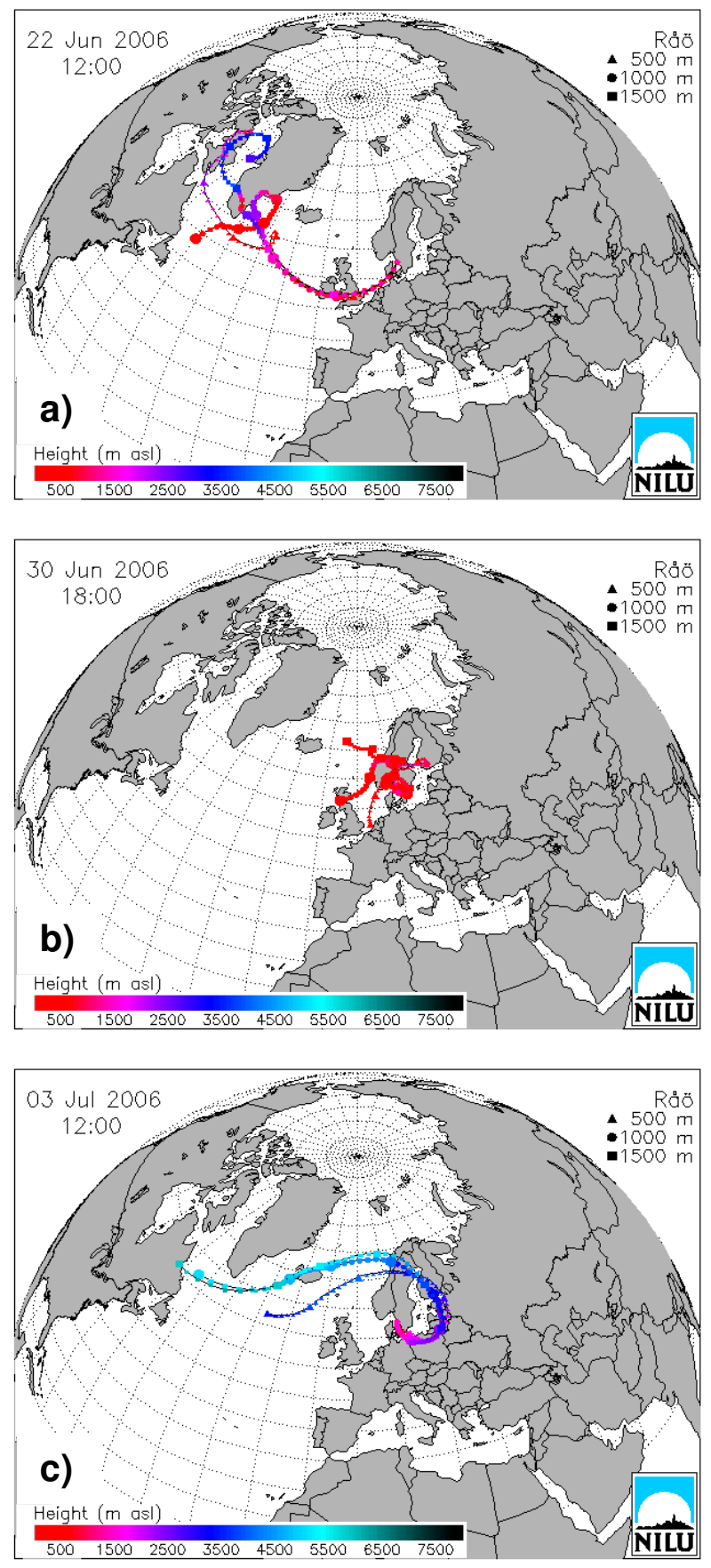

Fig. 2. Examples of FLEXTRA ten-days back trajectories (Stohl and Seibert, 1998) for air masses reaching Råö, which originate from UK/North Sea/Denmark (a), Scandinavia (b), and the Baltic Sea (c) during summer 2006.

more to the aerosol loading at the two sites. As listed in Table 3, the samples collected during the periods 1114 February and 14-18 February were influenced by Central/Eastern European air masses, whereas the sample collected from the 25 February-4 March was affected by air masses originating from Scandinavia. The sample collected in the intermediate period, 18-25 February, was influenced by both source regions. The summer campaign was characterized by westerly/south-westerly winds and changing cyclonic/anticyclonic conditions. Whereas air from the UK was transported over the North Sea or the coastal regions of Continental Europe to Denmark and Sweden during the first part of the period, the latter was dominated by local Scandinavian air masses. The periods 20-27 June and 27 June-4 July are characterized by westerly winds and by Scandinavian air, respectively. During the latter episode, the back trajectory calculations showed that the air masses traveled close to ground shortly before the sampling site, suggesting a possible contribution from local emission sources.

\subsection{Concentrations of carbonaceous particles}

For both winter and summer campaigns, Fig. 3 shows TC, OC (separated for WINSOC and WSOC), and EC concentrations, while Table 4 presents corresponding TC concentrations and EC/TC as well as WSOC/OC ratios. During the winter campaign, the TC concentration $\left(2.1-3.6 \mu \mathrm{g} \mathrm{m}^{-3}\right)$ at the urban site was approximately a factor of two higher compared to the rural site. The mean EC/TC ratio was only slightly higher at the urban site $(0.30 \pm 0.04)$ compared to the rural site $(0.24 \pm 0.01)$, whereas the WSOC/OC ratio was substantially higher at the rural site $(0.61 \pm 0.05)$ compared to the urban site $(0.48 \pm 0.06)$. For summer, the TC concentration at Femman was $2.2-3.0 \mu \mathrm{g} \mathrm{m}^{-3}$ and, therefore, comparable to the winter measurements. However, the EC/TC ratios were substantially lower during summer $(0.17 \pm 0.04)$, whereas WSOC/OC ratios were similar for both seasons.

\subsection{Results of ${ }^{14} \mathrm{C}$ analysis}

Table 4 shows the modern carbon fraction $\left(f_{M}\right.$, see Sect. 2.3) of EC, OC, WSOC and WINSOC. In winter, $f_{M}$ (EC) was substantially lower for the urban site $(0.12 \pm 0.03)$ compared to the rural site $(0.39 \pm 0.05)$, showing a higher relative contribution of fossil fuel sources to EC at the urban site, which most likely is attributed to the influence of vehicular traffic as discussed in detail below. For the winter, ${ }^{14} \mathrm{C}$ isotope signals of $\mathrm{OC}$ and its sub-fractions were identical within uncertainties between both sites and average values for $f_{M}(\mathrm{OC})$, $f_{M}$ (WINSOC), and $f_{M}$ (WSOC) were $0.70,0.54$, and 0.83 , respectively. The average $f_{M}$ (EC) was similar during summer and winter for the urban site, however, $f_{M}(\mathrm{EC})$ showed higher variability during summer compared to winter. Concentrations of total $\mathrm{EC}$ and $\mathrm{EC}_{\text {fossil }}$ were higher by a factor of 2.4 and 3.1, respectively, at the urban site compared to the rural site, whereas $\mathrm{EC}_{\text {wood }}$ was about the same level at the two sites or even moderately increased at the rural station. This implies that the spatial variability of wood-burning emissions between the two sites (and, probably, in the whole region) during winter are moderate, whereas the contribution 
Table 3. Source regions of air masses reaching Råö according to FLEXTRA ten-days back trajectories (Stohl and Seibert, 1998). Typical trajectories are shown in Figs. 1 and 2.

\begin{tabular}{lccc}
\hline Sample & Period & Wind direction & Source regions \\
\hline 11-14 Feb 05 & 11-12 Feb & W/NW & Greenland, Atlantic Ocean \\
& 13-14 Feb & E/NE & Central Europe, Baltic states \\
14-18 Feb 05 & 14-17 Feb & NE & Ukraine, Russia, Finland \\
& 18 Feb & W & Atlantic Ocean \\
18-25 Feb 05 & 18-19 Feb & W/NW & Atlantic Ocean \\
& 20-21 Feb & N/NE & Arctic Ocean, Scandinavia \\
& 21-25 Feb & E/NE & Ukraine, Russia, Finland \\
25 Feb-04 Mar 05 & 25 Feb-04 Mar & N/NE & Arctic Ocean, Scandinavia \\
\hline 13-20 Jun 06 & 13-14 Jun & W/SW & UK, North Sea, Denmark \\
& 15-17 Jun & variable & Scandinavia \\
18-20 Jun & W/SW & UK, North Sea, Denmark \\
20-27 Jun 06 & 20-27 Jun & W/SW & UK, North Sea, Denmark \\
27 Jun-4 Jul 06 & 27 Jun-2 Jul & variable & Scandinavia \\
& 2-4 Jul & S/SE & Baltic Sea (coastal and open sea) \\
\hline
\end{tabular}
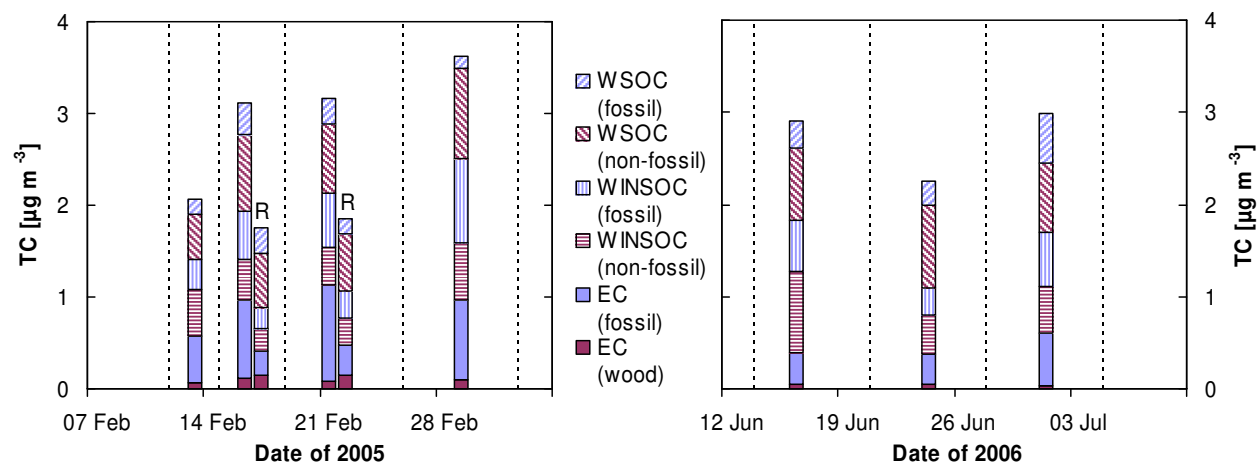

Fig. 3. Contributions of fossil and non-fossil sources to EC and OC during winter 2005 (left) and summer 2006 (right). Results from the rural site Råö are only available for winter 2005 and are indicated by "R". Vertical lines mark beginning and end of aerosol sampling.

of fossil sources to EC strongly depend on the urban vs. rural site characteristics. During summer, EC concentrations were about half of that observed in winter level with small wood-burning contributions.

Figure 3 shows OC concentrations divided into watersoluble and water-insoluble organic carbon, which have been separated with respect to fossil and non-fossil sources. The WSOC fraction was dominated by non-fossil sources for all samples with an average non-fossil contribution of $70 \%$, which did not differ significantly between the sites and seasons. WINSOC comprised a similar fossil and non-fossil content with average non-fossil contributions of $47 \%, 51 \%$, and $56 \%\left(f_{M}: 0.52,0.56\right.$, and 0.61$)$ for urban/winter, rural/winter, and urban/summer conditions, respectively. Figure 3 indicates that the urban vs. rural difference during winter were more pronounced for WINSOC than for WSOC: whereas the urban/rural ratio of fossil
WINSOC concentrations amounted to 2.1 , these ratios were 1.6, 1.4 and 1.3 for non-fossil WINSOC, fossil and nonfossil WSOC, respectively. Consequently, fossil WINSOC is the sub-fraction of OC that is influenced the most by the urban environment, while fossil WSOC and, thus, fossil SOA seems to be more regional in character. For summer, the composition of OC was comparable to winter at the urban site with the exception that the water-soluble vs. waterinsoluble distribution for fossil OC was shifted to WSOC for summer.

\subsection{Levoglucosan measurements}

The monosaccharide anhydrides levoglucosan, mannosan and galactosan were analysed, whilst only the mean concentration of levoglucosan is reported here (Table 4, Fig. 4). Levoglucosan was the most abundant isomer regardless of site and season, accounting for $69 \pm 4 \%$ of the sum of the 
Table 4. TC concentrations, EC/TC as well as WSOC/OC ratios, $f_{M}$ determinations and concentrations of levoglucosan (lev), $\mathrm{NO}_{\mathrm{x}}$, as well as $\mathrm{CO}$ at the urban and the rural site during winter 2005 and summer 2006. All values are presented with combined measurement uncertainties $(1 \sigma)$.

\begin{tabular}{|c|c|c|c|c|c|c|c|c|c|c|}
\hline Sample & $\mathrm{TC}\left[\mu \mathrm{g} \mathrm{m}^{-3}\right]$ & $\mathrm{EC} / \mathrm{TC}$ & WSOC/OC & $f_{M}(\mathrm{EC})$ & $f_{M}(\mathrm{OC})$ & $f_{M}$ (WINSOC) & $f_{M}(\mathrm{WSOC})$ & $\operatorname{Lev}\left[\mu \mathrm{g} \mathrm{m}^{-3}\right]$ & $\mathrm{NO}_{\mathrm{x}}\left[\mu \mathrm{g} \mathrm{m}^{-3}\right]$ & $\mathrm{CO}\left[\mathrm{mg} \mathrm{m}^{-3}\right]$ \\
\hline \multicolumn{11}{|l|}{ Winter, urban } \\
\hline $11-14$ Feb 05 & $2.1 \pm 0.1$ & $0.28 \pm 0.04$ & $0.44 \pm 0.06$ & $0.14 \pm 0.03$ & $0.74 \pm 0.02$ & $0.67 \pm 0.02$ & $0.82 \pm 0.05$ & $0.06^{\#}$ & 24 & 0.06 \\
\hline $14-18$ Feb $05^{*}$ & $3.1 \pm 0.2$ & $0.31 \pm 0.04$ & $0.55 \pm 0.06$ & $0.15 \pm 0.02$ & $0.67 \pm 0.02$ & $0.52 \pm 0.02$ & $0.79 \pm 0.05$ & $0.05^{\#}$ & 37 & 0.08 \\
\hline $18-25$ Feb $05^{*}$ & $3.2 \pm 0.2$ & $0.35 \pm 0.05$ & $0.51 \pm 0.06$ & $0.08 \pm 0.01$ & $0.63 \pm 0.02$ & $0.46 \pm 0.01$ & $0.80 \pm 0.05$ & $0.06^{\#}$ & 46 & 0.12 \\
\hline $25 \mathrm{Feb}-4$ Mar 05 & $3.6 \pm 0.2$ & $0.27 \pm 0.03$ & $0.42 \pm 0.06$ & $0.11 \pm 0.01$ & $0.67 \pm 0.02$ & $0.45 \pm 0.01$ & $0.98 \pm 0.08$ & $0.07^{\#}$ & 62 & 0.11 \\
\hline Average & $3.0 \pm 0.7$ & $0.30 \pm 0.04$ & $0.48 \pm 0.06$ & $0.12 \pm 0.03$ & $0.68 \pm 0.04$ & $0.52 \pm 0.10$ & $0.85 \pm 0.09$ & $0.06 \pm 0.01$ & $42 \pm 16$ & $0.09 \pm 0.03$ \\
\hline \multicolumn{11}{|l|}{ Winter, rural } \\
\hline $14-18 \mathrm{Feb} 05^{*}$ & $1.8 \pm 0.1$ & $0.24 \pm 0.03$ & $0.65 \pm 0.06$ & $0.42 \pm 0.06$ & $0.68 \pm 0.02$ & $0.55 \pm 0.04$ & $0.75 \pm 0.05$ & 0.02 & - & - \\
\hline $18-25$ Feb $05^{*}$ & $1.9 \pm 0.1$ & $0.25 \pm 0.03$ & $0.57 \pm 0.06$ & $0.35 \pm 0.03$ & $0.74 \pm 0.02$ & $0.57 \pm 0.02$ & $0.87 \pm 0.04$ & 0.05 & - & - \\
\hline Average & $1.8 \pm 0.1$ & $0.24 \pm 0.01$ & $0.61 \pm 0.05$ & $0.39 \pm 0.05$ & $0.71 \pm 0.04$ & $0.56 \pm 0.02$ & $0.81 \pm 0.08$ & $0.04 \pm 0.02$ & - & - \\
\hline \multicolumn{11}{|l|}{ Summer, urban } \\
\hline 13-20 Jun 06 & $2.9 \pm 0.2$ & $0.13 \pm 0.02$ & $0.43 \pm 0.06$ & $0.13 \pm 0.02$ & $0.73 \pm 0.01$ & $0.68 \pm 0.01$ & $0.80 \pm 0.03$ & 0.01 & 28 & 0.38 \\
\hline 20-27 Jun 06 & $2.2 \pm 0.1$ & $0.17 \pm 0.02$ & $0.62 \pm 0.06$ & $0.17 \pm 0.03$ & $0.78 \pm 0.01$ & $0.64 \pm 0.01$ & $0.87 \pm 0.03$ & 0.03 & 19 & 0.35 \\
\hline 27 Jun-4 Jul 06 & $3.0 \pm 0.2$ & $0.20 \pm 0.02$ & $0.54 \pm 0.06$ & $0.05 \pm 0.02$ & $0.59 \pm 0.01$ & $0.52 \pm 0.01$ & $0.65 \pm 0.02$ & 0.01 & 44 & 0.31 \\
\hline Average & $2.7 \pm 0.4$ & $0.17 \pm 0.04$ & $0.53 \pm 0.10$ & $0.12 \pm 0.06$ & $0.70 \pm 0.10$ & $0.61 \pm 0.08$ & $0.78 \pm 0.11$ & $0.02 \pm 0.01$ & $30 \pm 12$ & $0.35 \pm 0.04$ \\
\hline
\end{tabular}

* Note that sampling was performed simultaneously at both sites.

\# Averaged from daily measurements, which ended on 2 March (see Fig. 4).

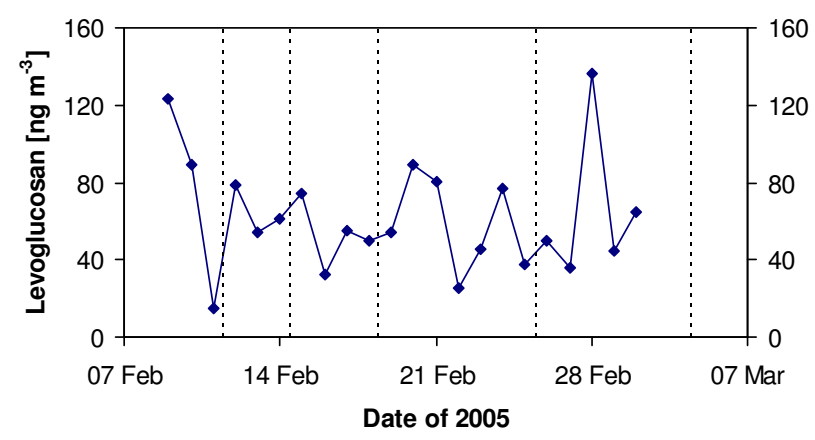

Fig. 4. 24-h mean concentrations of levoglucosan for the urban site during the winter campaign 2005. The vertical lines mark the time periods during which aerosol filter samples were collected for subsequent ${ }^{14} \mathrm{C}$ analysis (see Fig. 3).

three isomers, followed by mannosan $(23 \pm 3 \%)$ and galactosan $(9 \pm 2 \%)$. The relative contribution of levoglucosan is in the lower range of what has been reported previously for European sites (e.g. Zdráhal et al., 2001; Pashynska et al., 2002; Yttri et al., 2005, 2008; Szidat et al., 2006).

A mean concentration of $62 \pm 30 \mathrm{ng} \mathrm{m}^{-3}$ levoglucosan was observed at the urban site Femman in Göteborg during wintertime sampling (Table 4). Concurrent measurements of levoglucosan at the rural site Råö showed a somewhat lower mean concentration $\left(35 \pm 20 \mathrm{ng} \mathrm{m}^{-3}\right)$. The mean concentration observed at the urban site in summer $\left(17 \pm 11 \mathrm{ng} \mathrm{m}^{-3}\right)$ was more than three times lower than the concentrations observed in winter. Increased concentrations of levoglucosan in winter compared to summer has previously been reported by Zdrahal et al. (2001) for Ghent (Belgium), Szidat et al. (2006) for Zurich (Switzerland), and Yttri et al. (2008) for Elverum (Norway), although more pronounced (up to factor of 20) than for Göteborg. The less evident seasonal variation observed in Göteborg is attributed to the low levels of levoglucosan in winter, while summertime levels are equal to those reported by Zdrahal et al. (2001) and Yttri et al. (2008).

The mean concentration of levoglucosan observed at the urban site in Göteborg is in the lower range of what has been reported for other major ( $>500000$ inhabitants) cities in Scandinavia during wintertime sampling, i.e. Copenhagen (Oliveira et al., 2007), Helsinki (Saarnio et al., 2006; Sillanpää et al., 2005) and Oslo (Yttri et al., 2005, 2008) (see Table 5). The difference is even larger when compared to small Scandinavian towns ( $<20000$ inhabitants), for which the mean concentrations of levoglucosan range between $0.2-$ $0.9 \mu \mathrm{g} \mathrm{m}^{-3}$ (Yttri et al., 2005; Hedberg et al., 2006; Glasius et al., 2008). Considerably higher concentrations of levoglucosan are reported even for cities in Continental and Southern Europe such as Amsterdam, Duisburg, Oporto and Prague (Sillanpää et al., 2005; Oliveira et al., 2007) (Table 5). It should be noted though that the levels presented by Sillanpää et al. (2005) were obtained during episodes with severe air pollution. Possible explanations to the lower levels of levoglucosan observed in Göteborg might be the state of combustion technology, the nature of the appliances used, and the extended use of district heating, as the production of levoglucosan is reduced for higher combustion temperatures (Schmidl et al., 2008).

A wide range of levoglucosan-to-OC emission ratios has been reported for various types of softwood and hardwood (Fine et al., 2002a; Simoneit et al., 1999). Further, levoglucosan-to-OC emission ratios have typically been established for US tree types (Fine et al. 2001, 2002a, b, 2004) using US appliances, which may not be applicable to Europe. Fine et al. (2002a) found that the levoglucosan-to-OC emission ratio ranged from $113-191 \mathrm{mg} \mathrm{g}^{-1}$ for ten regions 
Table 5. Concentrations $\left(\mu \mathrm{g} \mathrm{m}^{-3}\right)$ of levoglucosan (lev) and monosaccharide anhydrides ( $\Sigma \mathrm{MA}$, i.e. sum of levoglucosan, mannosan and galactosan) reported for European urban areas during wintertime.

\begin{tabular}{|c|c|c|c|c|c|c|c|}
\hline Study & Site & Category & $n$ & Date & Size & Lev & $\Sigma \mathrm{MA}$ \\
\hline Zdrahal et al., 2002 & Ghent (Belgium) & Urban background & 8 & 1998 (Jan-Mar) & $\mathrm{PM}_{10}$ & 0.48 & 0.56 \\
\hline Paschynska et al., 2002 & Ghent (Belgium) & Urban background & 9 & 2000/01 (Nov-Mar) & $\mathrm{PM}_{10}$ & 0.42 & 0.51 \\
\hline \multirow[t]{2}{*}{ Yttri et al., 2005} & Oslo (Norway) & Urban background & 24 & 2001 (Nov-Dec) & $\mathrm{PM}_{10}$ & $0.17 \pm 0.15$ & $0.21 \pm 0.19$ \\
\hline & Elverum (Norway) & Urban background & 25 & 2002 (Jan-Mar) & $\mathrm{PM}_{10}$ & $0.41 \pm 0.22$ & $0.53 \pm 0.28$ \\
\hline Sillanpää et al., 2005; & Amsterdam (NL) & Urban background & 14 & 2003 (Jan-Mar) & $\mathrm{PM}_{2.5}$ & - & $0.36 \pm 0.25$ \\
\hline \multirow[t]{3}{*}{ Saarikoski et al., 2008} & Duisburg (Germany) & Urban background & 14 & 2002 (Oct-Nov) & $\mathrm{PM}_{2.5}$ & - & $0.23 \pm 0.13$ \\
\hline & Helsinki (Finland) & Urban background & 15 & 2002 (Mar-May) & $\mathrm{PM}_{2.5}$ & - & $0.08 \pm 0.07$ \\
\hline & Prague $(\mathrm{CZ})$ & Urban background & 13 & 2002/03 (Nov-Jan) & $\mathrm{PM}_{2.5}$ & - & $1.32 \pm 0.50$ \\
\hline Hedberg et al., 2006 & Lycksäle (Sweden) & Urban background & 15 & 2002 (Jan-Mar) & $\mathrm{PM}_{10}$ & 0.90 & - \\
\hline \multirow[t]{2}{*}{ Saarnio et al., 2006} & Helsinki (Finland) & Urban background & 9 & 2004 (Jan-Feb) & $\mathrm{PM}_{2.5}$ & - & $0.25 \pm 0.14$ \\
\hline & Kotka (Finland) & Urban background & 20 & 2005/06 (Nov-May) & $\mathrm{PM}_{2.5}$ & - & $0.07 \pm 0.04$ \\
\hline Szidat et al., 2006 & Zurich (Switzerland) & Urban background & 2 & $2003(\mathrm{Feb})$ & $\mathrm{PM}_{10}$ & $0.62 \pm 0.16$ & - \\
\hline Sandradewi et al., $2008 \mathrm{~b}$ & Zurich (Switzerland) & Urban background & 7 & 2006 (Jan) & $\mathrm{PM}_{1}$ & $0.31 \pm 0.16$ & $0.41 \pm 0.21$ \\
\hline \multirow[t]{4}{*}{ Oliveira et al., 2007} & Oporto (Portugal) & Urban background & 28 & 2003 (Nov-Dec) & $\mathrm{PM}_{10}$ & $0.12 \pm 0.08$ & - \\
\hline & & Roadside & 28 & 2003 (Nov-Dec) & $\mathrm{PM}_{10}$ & $0.17 \pm 0.10$ & - \\
\hline & Copenhagen (DK) & Urban background & 27 & 2004 (Feb-Mar) & $\mathrm{PM}_{10}$ & $0.06 \pm 0.04$ & - \\
\hline & & Roadside & 27 & 2004 (Feb-Mar) & $\mathrm{PM}_{10}$ & $0.11 \pm 0.06$ & - \\
\hline \multirow[t]{2}{*}{ Glasius et al., 2008} & Vindinge (Denmark) & Urban background & 10 & 2005 (Feb-Apr) & $\mathrm{PM}_{2.5}$ & $0.17 \pm 0.09$ & - \\
\hline & & Residential & 10 & 2005 (Feb-Apr) & $\mathrm{PM}_{2.5}$ & $0.31 \pm 0.24$ & - \\
\hline \multirow[t]{2}{*}{ This study } & Göteborg & Urban background & 22 & 2005 (Feb-Mar) & $\mathrm{PM}_{2.5}$ & $0.06 \pm 0.03$ & $0.09 \pm 0.05$ \\
\hline & Råö & Rural & 2 & 2005 (Feb-Mar) & $\mathrm{PM}_{10}$ & $0.04 \pm 0.02$ & - \\
\hline
\end{tabular}

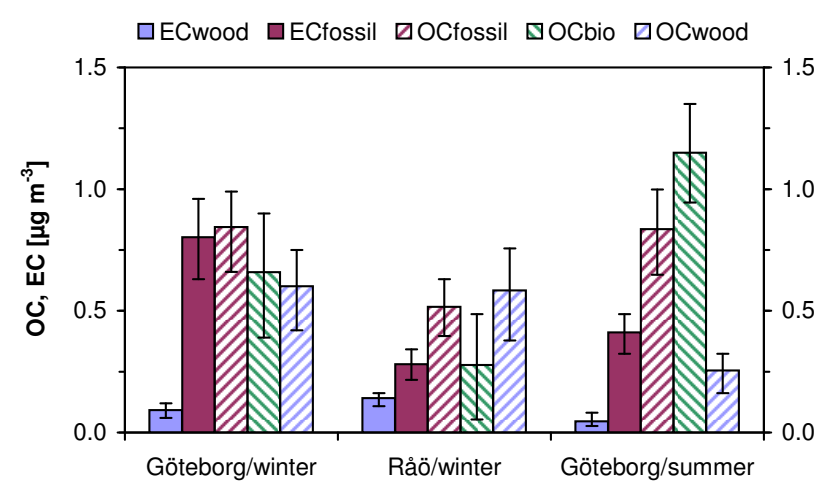

Fig. 5. Average concentrations of different carbonaceous particle fractions for the three campaigns. Uncertainty bars represent 10 and 90 percentiles from LHS calculations. Results of the single filters are shown in Table 6.

covering the entire US, when normalizing with respect to local tree types and appliances used. Thus, levoglucosan accounted for $14 \pm 2 \%$ of the fine OC emission. Emission ratios for European tree types are scarce. Puxbaum et al. (2007) reported a levoglucosan-to-OC-ratio $\left(\mathrm{PM}_{10}\right)$ of $14 \%$ based on test burns of beech $(7.9 \%)$ and spruce $(20.6 \%)$. Considering these European studies (and accounting to some extent for the high values found in Hedberg et al., 2006), Simpson et al. (2007) suggested a central-estimate of $13 \%$, ranging between 6.5 and $26 \%$.
For Scandinavia, Yttri et al. (2008) found levoglucosan/OC emission ratios of $8.9 \%$ (likely range $7.1-12 \%$ ) for $\mathrm{PM}_{2.5}$ and $6.7 \%$ (range 5.6-9.1\%) for $\mathrm{PM}_{10}$, in an area almost exclusively influenced by residential wood burning. That study accounted for the positive sampling artifacts of $\mathrm{OC}$ and so likely produced higher levoglucosan/OC ratios than are applicable for our work. By allowing for this difference between both studies and considering other studies, we chose a levoglucosan/OC emission ratio of $10 \%$ (range $7.2-18 \%)$. This is equivalent to $(\mathrm{OC} / \mathrm{lev})_{\text {wood }}$ of 10 (range 5.5-14), which is used in this work (Table 2).

\subsection{Source apportionment results}

Table 6 gives concentrations of EC and OC distinguished into different sources. Figure 5 presents averages for the three campaigns. The determination of $\mathrm{EC}_{\text {fossil }}$ and $\mathrm{EC}_{\mathrm{wood}}$ as well as $\mathrm{OC}_{\text {fossil }}$ and $\mathrm{OC}_{\text {nonfossil }}$ is based on ${ }^{14} \mathrm{C}$ analysis (see Sect. 2.5). For the separation of $\mathrm{OC}_{\text {nonfossil }}$ into $\mathrm{OC}_{\mathrm{wood}}$ and $\mathrm{OC}_{\text {bio }},{ }^{14} \mathrm{C}$ and levoglucosan measurements were used in combination. The uncertainties of these sources were calculated with LHS as described in Sect. 2.5 allowing for complex parameter combinations and asymmetric confidential bands. These ranges represent the probability distribution (10 and 90 percentile) of that component's contribution, indicating the most-likely value for each component and its precision. LHS was especially helpful for the determination of $\mathrm{OC}_{\text {wood. }}{ }^{14} \mathrm{C}$ and levoglucosan enable independent estimations of this source. However, both approaches require 
Table 6. Concentrations $\left(\mu \mathrm{g} \mathrm{m}^{-3}\right)$ of different carbonaceous particle fractions. Distributions from Latin-hypercube sampling (LHS) calculations (Gelencsér et al., 2007) are given as medians with 10 and 90 percentiles. For averages see Fig. 5.

\begin{tabular}{lccccc}
\hline Sample & $\mathrm{EC}_{\text {fossil }}$ & $\mathrm{EC}_{\text {wood }}$ & $\mathrm{OC}_{\text {fossil }}$ & $\mathrm{OC}_{\text {wood }}$ & $\mathrm{OC}_{\text {bio }}$ \\
\hline Winter, urban & & & & & \\
11-14 Feb 05 & $0.51(0.40,0.61)$ & $0.07(0.04,0.08)$ & $0.53(0.40,0.65)$ & $0.53(0.38,0.67)$ & $0.46(0.23,0.67)$ \\
14-18 Feb 05* & $0.83(0.65,0.99)$ & $0.12(0.09,0.16)$ & $0.88(0.68,1.05)$ & $0.65(0.43,0.84)$ & $0.61(0.28,0.90)$ \\
18-25 Feb 05* & $1.02(0.80,1.22)$ & $0.08(0.03,0.10)$ & $0.94(0.77,1.09)$ & $0.55(0.38,0.67)$ & $0.61(0.32,0.86)$ \\
25 Feb-04 Mar 05 & $0.88(0.68,1.04)$ & $0.09(0.07,0.14)$ & $1.07(0.83,1.26)$ & $0.65(0.47,0.83)$ & $0.91(0.61,1.19)$ \\
Winter, rural & & & & & \\
14-18 Feb 05* & $0.27(0.20,0.32)$ & $0.15(0.11,0.18)$ & $0.55(0.43,0.65)$ & $0.49(0.23,0.72)$ & $0.34(0.07,0.59)$ \\
18-25 Feb 05* & $0.33(0.25,0.38)$ & $0.14(0.10,0.17)$ & $0.50(0.38,0.61)$ & $0.65(0.44,0.82)$ & $0.29(0.06,0.51)$ \\
Summer, urban & & & & & \\
13-20 Jun 06 & $0.34(0.26,0.38)$ & $0.04(0.03,0.09)$ & $0.87(0.64,1.07)$ & $0.19(0.09,0.26)$ & $1.47(1.25,1.68)$ \\
20-27 Jun 06 & $0.32(0.24,0.37)$ & $0.06(0.02,0.07)$ & $0.56(0.37,0.70)$ & $0.33(0.22,0.40)$ & $0.94(0.75,1.12)$ \\
27 Jun-04 Jul 06 & $0.57(0.45,0.66)$ & $0.02(0.00,0.06)$ & $1.13(0.93,1.29)$ & $0.14(0.09,0.18)$ & $1.14(0.96,1.29)$ \\
\hline
\end{tabular}

* Note that sampling was performed simultaneously at both sites.

OC-to-tracer emission ratios from laboratory studies, which often show high variabilities. In order to improve the reliability of $\mathrm{OC}_{\mathrm{wood}}$, results of both approaches were combined using LHS. The broad distributions of $\mathrm{OC}_{\mathrm{wood}}$ (and $\mathrm{OC}_{\mathrm{bio}}$ accordingly) originate mainly from uncertainties of the input parameters. Furthermore, considerable differences between the ${ }^{14} \mathrm{C}$ and the levoglucosan approach occurred for a few samples: for 11-14 February at Femman and 14-18 February at Råö, 90\% confidential bands of both approaches did not overlap. The reasons for this large difference remain unclear. Major uncertainties may derive from variable tracerto-OC emission ratios for both, levoglucosan and ${ }^{14} \mathrm{C}$, due to spatially and temporarily changing burning and emission conditions. Furthermore, method-dependent differences between sites or seasons cannot be excluded as well, especially for the separation of OC and EC (Penner and Novakov, 1996; Szidat et al., 2004c), which is necessary for the estimation of $\mathrm{OC}_{\text {wood }}$ with ${ }^{14} \mathrm{C}$. As shown in Table 6, typical uncertainties (90\% confidence) amount to $20 \%$ for the separation of EC into $\mathrm{EC}_{\text {fossil }}$ and $\mathrm{EC}_{\text {wood }}$ as well as for $\mathrm{OC}$ into $\mathrm{OC}_{\text {fossil }}$ and $\mathrm{OC}_{\text {nonfossil }}$, whereas they are higher for the determination of $\mathrm{OC}_{\text {bio }}$ and $\mathrm{OC}_{\mathrm{wood}}$ : for $\mathrm{OC}_{\mathrm{wood}}$, uncertainties reach $30-50 \%$, which result in uncertainties for $\mathrm{OC}_{\mathrm{bio}}$ of $20 \%$ for summer and $>30 \%$ for winter. For Råö, the uncertainty ranges are much larger than for Femman. Thus, the source allocation for Femman seems much more robust than that for Råö.

\section{Discussion}

\subsection{Local and seasonal intercomparison}

Source apportionment of the carbonaceous aerosol from Table 6 is summarized in Figs. 5 and 6 and compared to previous results from Zurich, Switzerland in Fig. 7. During the winter campaign, the urban impact is more pronounced for the urban site compared to the rural site, as seen from the higher carbonaceous aerosol concentration and a higher EC/TC ratio. Furthermore, the contribution of fossil sources is relatively larger at the urban site as shown by the EC fraction, which originates nearly exclusively from fossil sources. The rural characteristics of the Råö site gives rise to a substantially higher relative importance of wood burning, which is indicated by the elevated contributions of $\mathrm{OC}_{\text {wood }}$ and $\mathrm{EC}_{\text {wood }}$ (Fig. 6). However, the absolute concentrations of wood burning aerosols (see $\mathrm{EC}_{\text {wood }}$ levels in Table 6 and Fig. 5) seem to be elevated only moderately at the rural compared to the urban site.

The presence of $\mathrm{OC}_{\text {bio }}$ during winter is consistent with model calculations suggesting that biogenic SOA can be formed in Scandinavia in the cold season (Simpson et al., 2007), even if both approaches, the ${ }^{14} \mathrm{C} /$ levoglucosan method and current modeling calculations, result in highly uncertain estimations of biogenic SOA concentrations for winter. However, the value for $\mathrm{OC}_{\text {bio }}$ may be overestimated due to the fact that the determination of $\mathrm{OC}_{\mathrm{wood}}$ is based on laboratory emission ratios (i.e., (OC/EC) $)_{\text {wood }}$ and $\left.(\mathrm{OC} / \mathrm{lev})_{\mathrm{wood}}\right)$, which mainly consider primary particle formation. Grieshop et al. (2008) demonstrated in smog chamber experiments that wood-burning SOA ( $\left.\mathrm{SOA}_{\text {wood }}\right)$ may reach up to similar levels as POA from the same source, which also was found as an upper estimate for winter aerosol at Zurich by

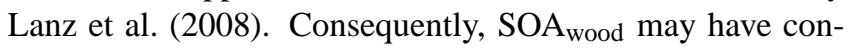
tributed to $\mathrm{OC}_{\text {bio }}$ at least partially. Nevertheless, the presence of $\mathrm{OC}_{\mathrm{bio}}$ during winter is still evident based on measurements of $f_{M}$ (EC), $f_{M}$ (WINSOC), and $f_{M}$ (WSOC) for the last winter sample at Femman (25 February-4 March) as discussed below. This is verified by an upper estimate of $\mathrm{SOA}_{\text {wood }}$ from the data in Table 6: for the simultaneous sampling episodes, average $\mathrm{OC}_{\mathrm{bio}} / \mathrm{OC}_{\mathrm{wood}}$ ratios amounted 


\section{a) Zurich/winter}
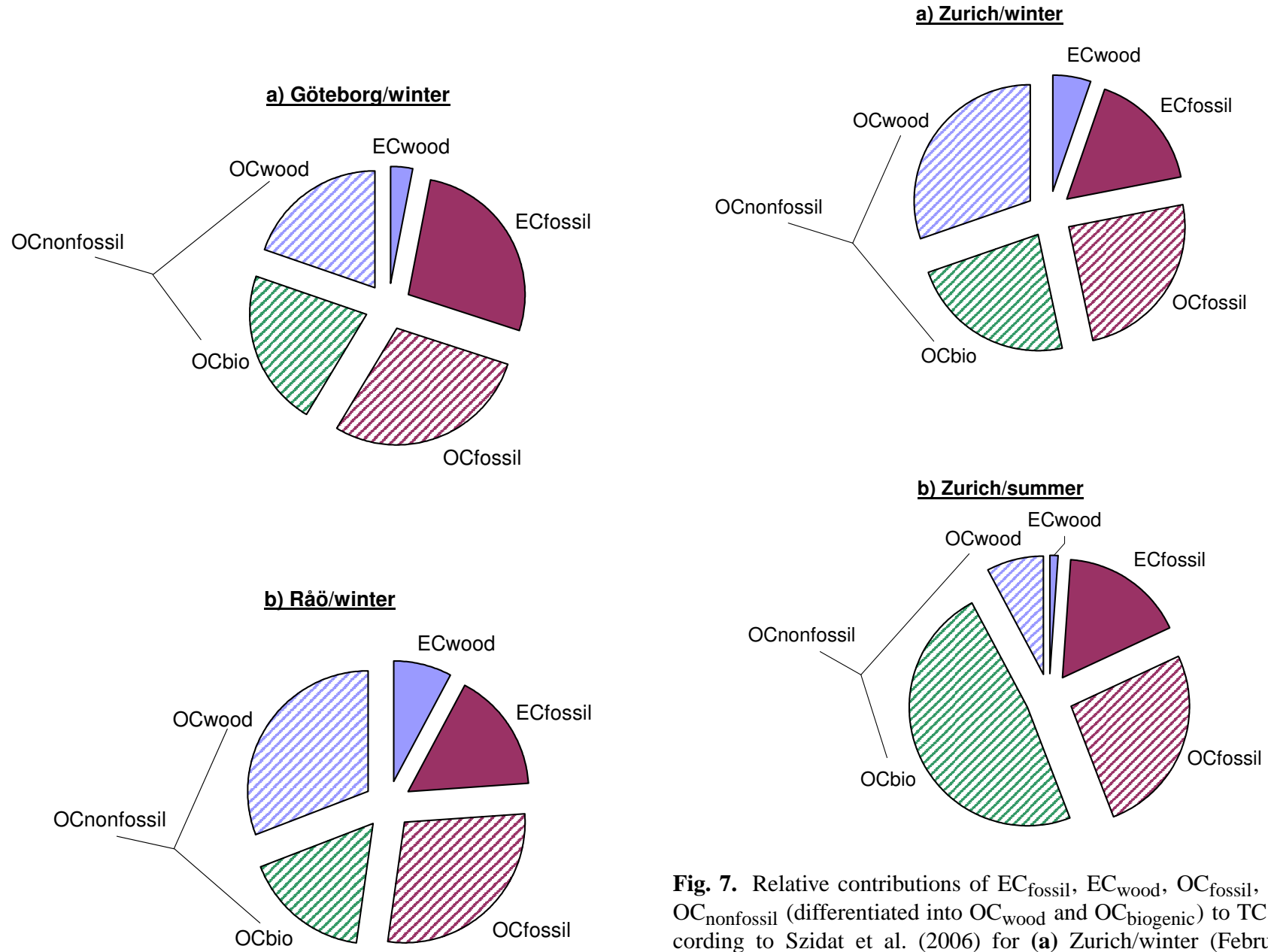

Fig. 7. Relative contributions of $\mathrm{EC}_{\text {fossil }}, \mathrm{EC}_{\mathrm{wood}}, \mathrm{OC}_{\text {fossil }}$, and $\mathrm{OC}_{\text {nonfossil }}$ (differentiated into $\mathrm{OC}_{\mathrm{wood}}$ and $\mathrm{OC}_{\text {biogenic }}$ ) to $\mathrm{TC}$ according to Szidat et al. (2006) for (a) Zurich/winter (February 2003), (b) Zurich/summer (August 2002).

to 0.6 and 1.0 for Råö and Femman, respectively; even if one assumes $\mathrm{OC}_{\text {bio }}$ completely to be composed of $\mathrm{SOA}_{\text {wood }}$ for the rural site, at least $40 \%$ of $\mathrm{OC}_{\text {bio }}$ actually remain as biogenic emissions for the urban site.

Comparing the results from the wintertime sampling in greater Göteborg with that reported for Zurich (Figs. 6 and 7 ), we found that the similarities were most pronounced for the rural site outside Göteborg rather than for the urban site. These similarities were related to the EC/TC ratios, fossil contributions, and $\mathrm{EC}_{\mathrm{wood}}$. We assume that the different histories of the air masses might cause this effect: whereas Göteborg is influenced by relatively clean air from marine or low-populated land areas, the air masses entering Zurich have traveled over moderately-populated regions with a rural character carrying aerosols that are accumulated over sev-

Fig. 6. Relative contributions of $\mathrm{EC}_{\text {fossil }}, \mathrm{EC}_{\mathrm{wood}}, \mathrm{OC}_{\text {fossil }}$, and $\mathrm{OC}_{\text {nonfossil }}$ (differentiated into $\mathrm{OC}_{\mathrm{wood}}$ and $\mathrm{OC}_{\text {biogenic }}$ ) to $\mathrm{TC}$ for (a) urban site Göteborg/winter, (b) rural site Råö/winter, and (c) urban site Göteborg/summer. eral days. Consequently, the local urban impact is better detectable at Göteborg. 
$\mathrm{OC}_{\mathrm{bio}}$ is the dominating source both in greater Göteborg and in Zurich during summer. In contrast to winter, the significant existence of this fraction is unquestionable for summer. For Zurich, OC was shown to originate mainly from biogenic SOA with minor contributions from primary biogenic OC (Szidat et al., 2004a, b), and the model calculations for Nordic sites by Simpson et al. (2007) would suggest a similar preponderance of SOA also for the Göteborg region. As a consequence of this additional summertime OC source, $\mathrm{EC} / \mathrm{TC}$ ratios are reduced compared to wintertime.

\subsection{Influence of air mass origin}

During the winter campaign, the first two samples (i.e., 1114 and 14-18 February) experienced air from Central and Eastern Europe. These are characterized by higher values for $f_{M}$ (EC) and $f_{M}$ (WINSOC), indicating a larger impact of EC and probably also of primary OC from wood burning. Aerosols in the last sample (25 February-4 March) were associated with air masses from Northern Scandinavia. This sample showed lower values for $f_{M}$ (EC) and $f_{M}$ (WINSOC), reflecting the increased urban influence of local fossil emissions for EC and primary OC, which were corroborated by high concentrations of $\mathrm{NO}_{\mathrm{x}}$. On the other hand, $f_{M}$ (WSOC) is nearly on the contemporary level, which means that SOA is marginally formed from fossil VOCs. This observation indicates presence of biogenic SOA, which has already been suggested for Pittsburgh during winter by Subramanian et al. (2007). Other possible contemporary sources are quite unlikely for the last sample (25 February-4 March): a) the effect from wood burning is small as revealed by the low $f_{M}(\mathrm{EC})$, which entails low EC, POA, and SOA emissions of this source. b) in contrast to our observations, cooking emissions should be detectable by high values for $f_{M}$ (WINSOC) rather than for $f_{M}$ (WSOC), as typical cooking tracers like fatty acids and cholesterol (Subramanian et al., 2007) are water insoluble; due to the vicinity of many restaurants at the Femman site, however, contributions from cooking cannot be excluded totally.

For the summer campaign, the second sample (20-27 June) was dominated by westerly/south-westerly winds carrying air masses from the UK and the North Sea over Denmark to Göteborg. For this sample, an unusually high $f_{M}$ (EC) value was determined, approximately 2.5 times higher than for average summer conditions in Zurich (Szidat et al., 2004a). According to MODIS fire maps (http: //rapidfire.sci.gsfc.nasa.gov/firemaps), hardly any wild fire activity occurred in the source region in the end of June 2006. Two causes may have been responsible for this high $f_{M}$ (EC) value: a) many small midsummer bonfires, which are traditionally lit in Scandinavia during this time without being visible on MODIS fire maps; b) remains of marine bioaerosols after the thermal pretreatment as discussed in Sect. 2.2. The last summer sample (27 June-4 July) experienced air masses from Central Scandinavia and the Baltic Sea region. Here,
EC was found to be nearly exclusively from fossil sources, which was observed for Zurich as well (Szidat et al., 2004a). Moreover, ${ }^{14} \mathrm{C}$ levels of OC, WINSOC, and WSOC were lower as well and $\mathrm{NO}_{\mathrm{x}}$ concentrations were higher compared to the other two summer samples, reflecting the importance of the local urban emissions from fossil sources for this sample. In particular, the $\sim 40 \%$ fossil fraction of WSOC - a proxy for fossil SOA - is remarkable, as it is twice as high as for Zurich (Szidat et al., 2004a, 2006).

\section{Conclusions}

Particulate matter was collected at the urban site Femman in Göteborg, Sweden, for a summer and a winter period. Concurrent measurements were performed at the rural site, Råö, $35 \mathrm{~km}$ south of Göteborg, during the winter period. The carbonaceous particle fractions EC, OC, WINSOC, and WSOC were sequentially separated from the filters by water extraction and oxidation. ${ }^{14} \mathrm{C} /{ }^{12} \mathrm{C}$ isotopic ratios were determined as fractions of modern carbon $\left(f_{M}\right)$ and fossil vs. non-fossil sources were apportioned for every fraction. Separate determination of the wood burning aerosol tracer compound levoglucosan made it possible to refine the contribution of this source using LHS calculations. The main results are:

- The urban site was strongly influenced by high relative contributions of fossil sources in winter, as seen from the low value of $f_{M}$ (EC) (0.12). The corresponding value for Råö (0.39) was more than three times larger than that observed at the urban site, and comparable to that reported for an urban site in Zurich (0.31), using the same methodology.

- In winter, the mean concentration of $\mathrm{EC}_{\mathrm{wood}}$ at the rural site $\left(0.15 \mu \mathrm{g} \mathrm{m}^{-3}\right)$ was slightly higher than that of the urban site $\left(0.09 \mu \mathrm{g} \mathrm{m}^{-3}\right)$, whereas the concentrations of $\mathrm{EC}_{\text {fossil }}$ was considerably lower $\left(0.30 \mu \mathrm{g} \mathrm{m}^{-3}\right.$ at the rural site compared to $0.81 \mu \mathrm{g} \mathrm{m}^{-3}$ at the urban site). This implies that the spatial variability of wood burning aerosols is moderate among both sites and high emissions of fossil EC decrease the relative contribution of biomass burning at the urban site.

- For winter, air masses originating from Scandinavia were characterized by high $f_{M}$ values for WSOC (0.98) and low $f_{M}$ values for EC (0.11), which suggests the abundance of biogenic SOA even in winter.

- For summer, $f_{M}$ (WSOC) indicated a relatively high fossil contribution to SOA $(\sim 40 \%)$ for aerosols at the urban site, which was of regional origin. This is approximately twice as high as for Zurich. The impact of wood burning was minor during the summer. 
Acknowledgements. This work was partly supported by the European Network of Excellence ACCENT (contract GOCE-CT2004-505337), the Swedish Foundation for Strategic Environmental Research MISTRA, the Norwegian SORGA project, the EU Program EUCAARI (European Integrated project on Aerosol Cloud Climate and Air Quality interactions) No 036833-2, and the EMEP network. We thank Miriam Wehrli (University of Berne) and Michael Sigl (PSI) for assistance with the ${ }^{14} \mathrm{C}$ measurements, Shuichi Hasegawa (National Institute for Environmental Studies, Japan) for providing $\mathrm{PM}_{2.5}$ data for Femman/summer, and Åsa Jonsson (Göteborg University) for help with flow calibration of sampling devices. NILU is acknowledged for providing an additional high-volume sampler during Göte-2005 and the FLEXTRA trajectories (www.nilu.no/trajectories) used in this study.

Edited by: U. Baltensperger

\section{References}

Alfarra, M. R., Prévôt, A. S. H., Szidat, S., Sandradewi, J., Weimar, S., Lanz, V. A., Schreiber, D., Mohr, M., and Baltensperger, U.: Identification of the mass spectral signature of organic aerosols from wood burning emissions, Environ. Sci. Technol., 41, 57705777, 2007.

Andersson-Sköld, Y. and Simpson, D.: Secondary organic aerosols formation in northern Europe: A model study, J. Geophys. Res., 106, 7357-7374, 2001.

Bond, T. C., Bhardwaj, E., Dong, R., Jogani, R., Jung, S., Roden, C., Streets, D. G., and Trautmann, N. M.: Historical emissions of black and organic carbon aerosols from energy-related combustion, 1850-2000, Global Biogeochem. Cy., 21, GB2018, doi:10.1029/2006GB002840, 2007.

Currie, L. A.: Evolution and multidisciplinary frontiers of ${ }^{14} \mathrm{C}$ aerosol science, Radiocarbon, 42, 115-126, 2000.

Dye, C. and Yttri, K. E.: Determination of monosaccharide anhydrides in atmospheric aerosols by use of high-resolution mass spectrometry combined with high performance liquid chromatography, Anal. Chem., 77, 1853-1858, 2005.

Fine, P. M., Cass, G. R., and Simoneit, B. R. T.: Chemical characterization of fine particle emissions from fireplace combustion of woods grown in the Northeastern United States, Environ. Sci. Technol., 35, 2665-2675, 2001.

Fine, P. M., Cass, G. R., and Simoneit, B. R. T.: Organic compounds in biomass smoke from residential wood combustion: Emissions characterization at a continental scale, J. Geophys. Res., 107(D21), 8349, doi:10.1029/2001JD000661, 2002a.

Fine, P. M., Cass, G. R., and Simoneit, B. R. T.: Chemical characterization of fine particle emissions from the fireplace combustion of woods grown in the Southern United States, Environ.Sci. Technol., 36, 1442-1451, 2002b.

Fine, P. M., Cass, G. R., and Simoneit, B. R. T.: Chemical characterization of fine particle emissions from the fireplace combustion of wood types grown in the Southern Midwestern and Western United States, Environ. Eng. Sci., 21, 387-409, 2004.

Fraser, M. P. and Lakshmanan, K.: Using levoglucosan as a molecular marker for the long-range transport of biomass combustion aerosols, Environ. Sci. Technol., 34, 4560-4564, 2000.
Gelencsér, A., May, B., Simpson, D., Sánchez-Ochoa, A., Kasper-Giebl, A., Puxbaum, H., Caseiro, A., Pio, C., and Legrand, M.: Source apportionment of $\mathrm{PM}_{2.5}$ organic aerosol over Europe: Primary/secondary, natural/anthropogenic, and fossil/biogenic origin, J. Geophys. Res., 112, D23S04, doi:10.1029/2006JD008094, 2007.

Glasius, M., Ketzel, M., Wåhlin, P., Jensen, B., Mønster, J., Berkowicz, R., and Palmgren, F.: Impact of wood combustion on particle levels in a residential area in Denmark, Atmos. Environ., 40, 7115-7124, doi:10.1016/j.atmosenv.2006.06.047, 2006.

Glasius, M., Ketzel, M., Wåhlin, P., Bossi, R., Stubkjær, J., Hertel, O., and Palmgren, F.: Characterization of particles from residential wood combustion and modelling of spatial variation in a low-strength emission area, Atmos. Environ., 42, 8686-8697, doi:10.1016/j.atmosenv.2008.04.037, 2008.

Grieshop, A. P., Donahue, N. M., and Robinson, A. L.: Laboratory investigation of photochemical oxidation of organic aerosol from wood fires - Part 2: Analysis of aerosol mass spectrometer data, Atmos. Chem. Phys. Discuss., 8, 17095-17130, 2008, http://www.atmos-chem-phys-discuss.net/8/17095/2008/.

Hallquist, M., Andersson, P. U., Boman, J., Emren, A., Hagström, M., Hasegawa, S., Janhäll, S., Langer, S., Ljungström, E., Nemitz, E., Olofsson. K. F. G., Pettersson, J. B. C., Synal, H.-A., Szidat, S., Shannigrahi, A. S., Svane, M., Thomas R., and Yttri, K. E.: Chemical characterisation of the urban aerosol during Göte-2005, Atmos. Chem. Phys., in preparation, 2009.

Hedberg, E., Kristensson, A., Ohlsson, M., Johansson, C., Johansson, P.-Å., Swietlicki, E., Vesely, V., Wideqvist, U., and Westerholm, R.: Chemical and physical characterization of emissions from birch wood combustion in a wood stove, Atmos. Environ., 36, 4823-4837, 2002.

Hedberg, E., Johansson, C., Johansson, L., Swietlicki, E., and Brorström-Lundén, E.: Is levoglucosan a suitable quantitative tracer for wood burning? Comparison with receptor modeling on trace elements in Lycksele, Sweden, J. Air Waste Manage., 56, 1669-1678, 2006.

Hopke, P. K., Ito, K., Mar, T., Christensen, W. F., Eatough, D. J., Henry, R. C., Kim, E., Laden, F., Lall, R., Larson, T. V., Liu, H., Neas, L., Pinto, J., Stölzel, M., Suh, H., Paatero, P., and Thurston, G. D.: PM source apportionment and health effects: 1. Intercomparison of source apportionment results, J. Expo. Anal. Env. Epid., 16, 275-286, 2006.

Jacobson, M. C., Hansson, H.-C., Noone, K. J., and Charlson, R. J.: Organic atmospheric aerosols: review and state of the science, Rev. Geophys., 38, 267-294, 2000.

Jenk, T. M., Szidat, S., Schwikowski, M., Gäggeler, H. W., Wacker, L., Synal, H.-A., and Saurer, M.: Microgram level radiocarbon $\left({ }^{14} \mathrm{C}\right)$ determination on carbonaceous particles in ice, Nucl. Instrum. Methods B, 259, 518-525, doi:10.1016/j.nimb2007.01.196, 2007.

Jordan, T. B. and Seen, A. J.: Effect of airflow setting on the organic composition of woodheater emissions, Environ. Sci. Technol., 39, 3601-3610, 2005.

Kanakidou, M., Seinfeld, J. H., Pandis, S. N., Barnes, I., Dentener, F. J., Facchini, M. C., Van Dingenen, R., Ervens, B., Nenes, A., Nielsen, C. J., Swietlicki, E., Putaud, J. P., Balkanski, Y., Fuzzi, S., Horth, J., Moortgat, G. K., Winterhalter, R., Myhre, C. E. L., Tsigaridis, K., Vignati, E., Stephanou, E. G., and Wilson, J.: Organic aerosol and global climate modelling: a review, Atmos. 
Chem. Phys., 5, 1053-1123, 2005,

http://www.atmos-chem-phys.net/5/1053/2005/.

Klingberg, J., Tang, L., Chen, D., Pihl Karlsson, G., Bäck, E., and Pleijel, $\mathrm{H}$.: Spatial variation of modelled and measured $\mathrm{NO}, \mathrm{NO}_{2}$ and $\mathrm{O}_{3}$ concentrations in the polluted urban landscape - relation to meteorology during the Göte-2005 campaign, Atmos. Chem. Phys. Discuss., 9, 2081-2111, 2009,

http://www.atmos-chem-phys-discuss.net/9/2081/2009/.

Knaapen, A. M., Borm, P. J. A., Albrecht, C., and Schins, R. P. F.: Inhaled particles and lung cancer, part A: mechanisms, Int. J. Cancer, 109, 799-809, 2004.

Lanz, V. A., Alfarra, M. R., Baltensperger, U., Buchmann, B., Hueglin, C., Szidat, S., Wehrli, M. N., Wacker, L., Weimer, S., Caseiro, A., Puxbaum, A., and Prévôt, A. S. H.: Source attribution of submicron organic aerosols during wintertime inversions by advanced factor analysis of aerosol mass spectra, Environ. Sci. Technol., 42, 214-220, doi:10.1021/es0707207, 2008.

Lavanchy, V. M. H., Gäggeler, H. W., Nyeki, S., and Baltensperger, U.: Elemental carbon (EC) and black carbon (BC) measurements with a thermal method and an aethalometer at the high-alpine research station Jungfraujoch, Atmos. Environ., 33, 2759-2769, 1999.

Levin, I. and Kromer, B.: The tropospheric ${ }^{14} \mathrm{CO}_{2}$ level in midlatitudes of the northern hemisphere (1959-2003), Radiocarbon, 46, 1261-1272, 2004.

Levin, I., Hammer, S., Kromer, B., and Meinhardt, F.: Radiocarbon observations in atmospheric $\mathrm{CO}_{2}$ : Determining fossil fuel $\mathrm{CO}_{2}$ over Europe using Jungfraujoch observations as background, Sci. Total Environ., 391, 211-216, 2008.

Lewis, C. W., Klouda, G. A., and Ellenson, W. D.: Radiocarbon measurement of the biogenic contribution to summertime $\mathrm{PM}_{2.5}$ ambient aerosol in Nashville, TN, Atmos. Environ., 38, 60536061, 2004.

Mohn, J., Szidat, S., Fellner, J., Rechberger, H., Quartier, R., Buchmann, B., and Emmenegger, L.: Determination of biogenic and fossil $\mathrm{CO}_{2}$ emitted by waste incineration based on ${ }^{14} \mathrm{CO}_{2}$ and mass balances, Bioresource Technol., 99, 64716479, doi:10.1016/j.biortech.2007.11.042, 2008.

Oliveira, C., Pio, C., Alves, C., Evtyugina, M., Santos, P., Goncalves, V., Nunes, T., Silvestre, A. J. D., Palmgren, F., Wahlin, P., and Harrad, S.: Seasonal distribution of polar organic compounds in the urban atmosphere of two large cities from the North and South of Europe, Atmos. Environ., 41, 5555-5570, 2007.

Pashynska, V., Vermeylen, R., Vas, G., Maenhaut, W., and Claeys, M.: Development of a gas chromatographic/ion trap mass spectrometric method for the determination of levoglucosan and saccharidic compounds in atmospheric aerosols. Application to urban aerosols, J. Mass Spectrom., 37, 1249-1257, 2002.

Penner, J. E. and Novakov, T.: Carbonaceous particles in the atmosphere: A historical perspective to the Fifth International Conference on Carbonaceous Particles in the Atmosphere, J. Geophys. Res., 101(D14), 19373-19378, 1996.

Perron, N., Szidat, S., Fahrni, S., Ruff, M., Wacker, L., Prévôt, A. S. H., and Baltensperger, U.: Optimized separation of OC and EC for radiocarbon source apportionment, Atmospheric Measurement Techniques, in preperation, 2009.

Pöschl, U.: Atmospheric aerosols: composition, transformation, climate and health effects, Angew. Chem. Int. Edit., 44, 7520-
7540, doi:10.1002/anie.200501122, 2005.

Puxbaum, H., Caseiro, A., Sanchez-Ochoa, A., Kasper-Giebl, A., Claeys, M., Gelencser, A., Legrand, M., Preunkert, S., and Pio, C.: Levoglucosan levels at background sites in Europe for assessing the impact of biomass combustion on the $\mathrm{Eu}-$ ropean aerosol background, J. Geophys. Res., 112, D23S05, doi:10.1029./2006JD008114, 2007.

Ruff, M., Wacker, L., Gäggeler, H. W., Suter, M., Synal, H.-A., and Szidat, S.: A gas ion source for radiocarbon measurements at 200 kV, Radiocarbon, 49, 307-314, 2007.

Saarikoski, S. K., Sillanpää, M. K., Saarnio, K. M., Hillamo, R. E., Pennanen, A. S., and Salonen, R. O.: Impact of biomass combustion on urban fine particulate matter in Central and Northern Europe, Water Air Soil Pollut., 191, 265-277, 2008.

Saarnio, K., Saarikoski, S., Sillanpää, M., Kuokka, S., Virkkula, A., and Hillamo, R.: Levoglucosan associated with biomass burning at atmospheric aerosols, in: NOSA 2006 aerosol symposium, edited by: Vehkamäki, H., Bergmann, T., Julin, J., Salonen, M., and Kulmala, M., Report Series in Aerosol Science no. 83, Helsinki, 330-334, 2006.

Sandradewi, J., Prévôt, A. S. H., Szidat, S., Perron, N., Alfarra, M. R., Lanz, V. A., Weingartner, E., and Baltensperger, U.: Using aerosol light absorption measurements for the quantitative determination of wood burning and traffic emission contributions to particulate matter, Environ. Sci. Technol., 42, 3316-3323, doi:10.1021/es702253m, 2008a.

Sandradewi, J., Prévôt, A. S. H., Alfarra, M. R., Szidat, S., Wehrli, M. N., Ruff, M., Weimer, S., Lanz, V. A., Weingartner, E., Perron, N., Caseiro, A., Kasper-Giebl, A., Puxbaum, H., Wacker, L., and Baltensperger, U.: Comparison of several wood smoke markers and source apportionment methods for wood burning particulate mass, Atmos. Chem. Phys. Discuss., 8, 8091-8118, 2008 , http://www.atmos-chem-phys-discuss.net/8/8091/2008/.

Schauer, J. J., Rogge, W. F., Hildemann, L. M., Mazurek, M. A., and Cass, G. R.: Source Apportionment of airborne particulate matter using organic compounds as tracers, Atmos. Environ., 30, 3837-3855, 1996.

Schmidl, C., Marr, I. L., Caseiro, A., Kotianová, P., Berner, A., Bauer, H., Kasper-Giebl, A., and Puxbaum, H.: Chemical characterisation of fine particle emissions from wood stove combustion of common woods growing in mid-European Alpine regions, Atmos. Environ., 42, 126-141, 2008.

Simoneit, B. R. T., Schauer, J. J., Nolte, C. G., Oros, D. R., Elias, V. O., Fraser, M. P., Rogge, W. F., and Cass, G. R.: Levoglucosan, a tracer for cellulose in biomass burning and atmospheric particles, Atmos. Environ., 33, 173-182, 1999.

Sillanpää, M., Frey, A., Hillamo, R., Pennanen, A. S., and Salonen, R. O.: Organic, elemental and inorganic carbon in particulate matter of six urban environments in Europe, Atmos. Chem. Phys., 5, 2869-2879, 2005,

http://www.atmos-chem-phys.net/5/2869/2005/.

Simpson, D., Yttri, K. E., Klimont, Z., Kupiainen, K., Caseiro, A., Gelencsér, A., Pio, C., Puxbaum, H., and Legrand, M.: Modeling carbonaceous aerosol over Europe: Analysis of the CARBOSOL and EMEP EC/OC campaigns, J. Geophys. Res., 112, D23S14, doi:10.1029/2006JD008158, 2007.

Stohl, A. and Seibert, P.: Accuracy of trajectories as determined from the conservation of meteorological tracers, Q. J. Roy. Me- 
teorol. Soc., 124, 1465-1484, 1998.

Stuiver, M. and Polach, H. A.: Reporting of ${ }^{14} \mathrm{C}$ data, Radiocarbon, 19, 355-363, 1977.

Subramanian, R., Donahue, N. M., Bernardo-Bricker, A., Rogge, W. F., and Robinson, A. L.: Insights into the primary-secondary and regional-local contributions to organic aerosol and $\mathrm{PM}_{2.5}$ mass in Pittsburgh, Pennsylvania, Atmos. Environ., 41, 74147433, 2007.

Synal, H.-A., Jacob, S., and Suter, M.: The PSI/ETH small radiocarbon dating system, Nucl. Instrum. Methods B, 172, 1-7, 2000.

Szidat, S., Jenk, T. M., Gäggeler, H. W., Synal, H.-A., Fisseha, R., Baltensperger, U., Kalberer, M., Samburova, V., Wacker, L., Saurer, M., Schwikowski, M., and Hajdas, I.: Source apportionment of aerosols by ${ }^{14} \mathrm{C}$ measurements in different carbonaceous particle fractions, Radiocarbon, 46, 475-484, 2004a.

Szidat, S., Jenk, T. M., Gäggeler, H. W., Synal, H.-A., Fisseha, R., Baltensperger, U., Kalberer, M., Samburova, V., Reimann, S., Kasper-Giebl, A., and Hajdas, I.: Radiocarbon $\left({ }^{14} \mathrm{C}\right)$-deduced biogenic and anthropogenic contributions to organic carbon (OC) of urban aerosols from Zürich, Switzerland, Atmos. Environ., 38, 4035-4044, 2004b.

Szidat, S., Jenk, T. M., Gäggeler, H. W., Synal, H.-A., Hajdas, I., Bonani, G., and Saurer, M.: THEODORE, a two-step heating system for the EC/OC determination of radiocarbon $\left({ }^{14} \mathrm{C}\right)$ in the environment, Nucl. Instrum. Methods B, 223-224, 829-836, 2004c.

Szidat, S., Jenk, T. M., Synal, H.-A., Kalberer, M., Wacker, L., Hajdas, I., Kasper-Giebl, A., and Baltensperger, U.: Contributions of fossil fuel, biomass burning, and biogenic emissions to carbonaceous aerosols in Zürich as traced by ${ }^{14} \mathrm{C}$, J. Geophys. Res., 111, D07206, doi:10.1029/2005JD006590, 2006.

Szidat, S., Prévôt, A. S. H., Sandradewi, J., Alfarra, M. R., Synal, H.-A., Wacker, L., and Baltensperger, U.: Dominant impact of residential wood burning on particulate matter in Alpine valleys during winter, Geophys. Res. Lett., 34, L05820, doi:10.1029/2006GL028325, 2007.
Szidat, S., Ruff, M., Wacker, L., Synal, H.-A., Hallquist, M., Shannigrahi, A. S., Yttri, K. E., Dye, C., and Simpson, D.: Interactive comment on "Fossil and non-fossil sources of organic carbon (OC) and elemental carbon (EC) in Gteborg, Sweden", Atmos Chem. Phys. Discuss., 8, S7525-S7530, 2008.

Szidat, S.: Sources of Asian haze, Science, 323, 470-471, 2009.

Tsigaridis, K., Krol, M., Dentener, F. J., Balkanski, Y., Lathiére, J., Metzger, S., Hauglustaine, D. A., and Kanakidou, M.: Change in global aerosol composition since preindustrial times, Atmos. Chem. Phys., 6, 5143-5162, 2006, http://www.atmos-chem-phys.net/6/5143/2006/.

Wittmaack, K.: Combustion characteristics of water-insoluble elemental and organic carbon in size selected ambient aerosol particles, Atmos. Chem. Phys., 5, 1905-1913, 2005, http://www.atmos-chem-phys.net/5/1905/2005/.

Yttri, K. E., Dye, C., Braathen, O.-A., Simpson, D., and Steinnes, E.: Carbonaceous aerosols at urban influenced sites in Norway, Atmos. Chem. Phys. Discuss., 8, 19487-19525, 2008, http://www.atmos-chem-phys-discuss.net/8/19487/2008/.

Yttri, K. E., Dye, C., Slørdal, L. H., and Braathen, O.-A.: Quantification of monosaccharide anhydrides by negative electrospray HPLC/HRMS-TOF - Application to aerosol samples from an urban and a suburban site influenced by small scale wood burning, J. Air Waste Manage., 55, 1169-1177, 2005.

Zdráhal, Z., Oliveira, J., Vermeylen, R., Claeys, M., and Maenhaut, W.: Improved method for quantifying levoglucosan and related monosaccharide anhydrides in atmospheric aerosols and application to samples from urban and tropical locations, Environ. Sci. Technol., 36, 747-757, 2002. 